International Research Journal of Management, IT \& Social Sciences
Available online at https://ijcujournals.us/journals/index.php/irjmis
Vol. 6 No. 1, January 2019, pages: $42 \sim 54$
ISSN: $2395-7492$
https://doi.org/10.21744/irjmis.v6n1.482

\title{
Communications Interaction of Mining Company to Community in Corporate Social Responsibility Program Implementation
}

Masrul ${ }^{a}$

Article history:

Received: 27 July 2018

Accepted: 30 November 2018

Published: 28 December 2018

\section{Keywords:}

communications interaction; community;

corporate social responsibility;

mining company;

program implementation;

\begin{abstract}
Communication Interaction of Mining Companies and Communities in the Implementation of Corporate Social Responsibility (CSR) Program. Study at PT. Anugrah Harisma Barakah (AHB) in Pongkalaero, Kabaena Selatan Subdistrict, Bombana Regency. The problems raised are first, how is the communication interaction of PT. Anugrah Harisma Barakah (AHB) in the community of Pongkalaero Village in the implementation of Corporate Social Responsibility (CSR) program? Second, what are the benefits of Corporate Social Responsibility (CSR) program to Pongkalaero community, South Kabaena Subdistrict, Bombana Regency? This study uses Social Relationships Theory approach is a theory that confirms that social relationships informally play an important role in changing a person's behavior when exposed to communication messages, messages are done through an intermediary or opinion leader. The results of this study indicate that the interaction of communication by mining companies PT. AHB to community Pongkalaero there are barriers even though the company uses communication interaction is more focused on opinion leaders in conveying information on CSR programs implemented in the community. However, CSR programs that have been implemented in the community are beneficial although not significant.
\end{abstract}

2395-7492 ${ }^{\circledR}$ Copyright 2019. The Author. Published by SLOAP. This is an open-access article under the CC-BY-SA license (https://creativecommons.org/licenses/by/4.0/) All rights reserved.

\footnotetext{
Author correspondence:

Masrul,

Universitas Halu Oleo, Communication Studies Program, Kendari,

Southeast Sulawesi, Indonesia

Email address: masrul1971@gmail.com
}

\section{Introduction}

The industry of mining companies in the vicinity of human settlements is always a concern. Efforts to interact between mining companies and communities are strongly connected to the success of mine. The plurality of characters confronted in the interaction between human beings demands effective communication strategies. Communication itself is a transaction, a symbolic process that requires people to manage their environment by building relationships

${ }^{\text {a }}$ Universitas Halu Oleo, Communication Studies Program, Kendari, Southeast Sulawesi, Indonesia 
among human beings through the exchange of information to strengthen knowledge, attitudes, and behavior of others, and even the effort to change attitudes and behavior through the exchange of information (Cangara 2011: 14).

The region of Southeast Sulawesi was buffeted by the hope of prosperity through industries engaged in mining such as PT. Anugrah Harisma Barakah (PT. AHB). The mining company is located in Pongkalaero Village, South Kabaena District, Bombana Regency which operates since 2010. The area has natural wealth in the form of nickel, so it becomes the main commodity in the company. Natural wealth is the great hope for the village community Pongkalaero. The existence of mining companies in the region will change the fate of life and bring prosperity and prosperity to the community in the company area. With regard to the euphoria of life and the demands of society are so echoing.

The atmosphere expressed by the public is realized by PT. Anugrah Harisma Barakah (AHB) is a consideration for continuous efforts to streamline the implementation of Corporate Social Responsibility (CSR). As a corporate social responsibility to the surrounding communities affected by the mining so it is expected to contribute to improving people's lives. Differences in the character of society, wants, needs, and even communications systems applied to companies often cause turmoil in the community.

Corporate Social Responsibility (CSR) both understanding and implementation is still a debate among businessmen and academics. CSR was originally a western concept so the main challenge was to provide means in accordance with the local context. The Government has arranged the CSR to be implemented by State-Owned Enterprises (BUMN) in Indonesia in Law No.40 of 2007 on Limited Liability Company (Perseroan Terbatas). Not only that but the design of communication integration in the community also gets constrained. Based on the above explanation, the authors conducted a study entitled Communications Interaction of Mining Companies to the Community in the Implementation of Corporate Social Responsibility (CSR) Program. Study: PT. Anugrah Harisma Barakah (AHB) In Pongkalaero Village, Kabaena Selatan District, Bombana Regency ".

\section{Research Question}

Based on the statement then the formulation of the issues to be discussed are:

1) How is the communication interaction of PT. Anugrah Harisma Barakah $(A H B)$ mining company in pongkalero Village community in implementing Corporate Social Responsibility (CSR) program?

2) What are the benefits of the Corporate Social Responsibility (CSR) program on communities in Pongkalero Village, South Kabaena District, Bombana Regency?

\section{Research Purposes}

The objectives of the study include:

1) To find out how the communication interaction of mining companies to the community in the implementation of Corporate Social Responsibility (CSR) program.

2) To find out what is the benefit of the Corporate Social Responsibility (CSR) program to the community in Pongkalaero Village, South Kabaena District, Bombana Regency.

\section{Research Benefit}

The benefits that can be obtained from this research are as follows:

1) Theoretically, this research is expected to give contribution in the framework of communication science development especially in developing the interaction relationship with the community.

2) Practically, this research is expected as input for the Bombala local government and PT. Anugrah Harisma Barakah $(A H B)$ in Developing CSR to the community in Pongkalaero Village, South Kabaena District, Bombana Regency.

3) Methodologically, this research is expected as material for other writers in reviewing the same research.

Masrul, -. (2018). Communications interaction of mining company to community in corporate social responsibility program implementation. International Research Journal of Management, IT and Social Sciences, 6(1), 42-54. https://doi.org/10.21744/irjmis.v6n1.482 


\section{Materials and Methods}

\section{Conceptual and Theoretical Framework Communication}

The term communication comes from the Latin word communicatio, and is derived from the word communis which means the same. The same meaning here means the same meaning. So, if two people engage in communication, for example in the form of a conversation, then the communication will happen or last as long as there is a common meaning about what will be spoken. The similarity of the language used in the conversation does not necessarily lead to the similarity of meaning. Meaning that understanding the spoken language alone does not necessarily produce the same meaning. Therefore the conversation of two people can be said communicative if both in addition to understanding the language used, also understand the meaning of the conversation (Effendy 2002: 9).

Harold Lasswell in "The structure and function of communication is a society "says that a good way to explain communication is to answer the question as follows: Who Says In Which Chanel To Whom With What Effects? So Lasswell's paradigm describes communication is the process of delivering messages by communicators to communicants through media that cause certain effects (Effendy 2002: 10). Based on the definition of communication that has been stated then the elements covered in the process of communication is:

1) Communicator, the person who delivered the message.

2) Messages, statements conveyed in the form of ideas, ideas, concepts in the form of symbols or symbols.

3) Communicant, the person receiving the message.

4) Channels (media) is a tool (tool) that supports the delivery of messages when the communicant far place or a lot of numbers.

5) Effects, impacts as a result of messages.

\section{Communication Process}

Effendy (2002: 7), mentioned and described some communication processes include:

a) The process of face to face communication

Face-to-face communication occurs because when communication takes place, communicators, and communicants facing each other while looking at each other. In communication situations like this communicator can see and review the communicant directly. Therefore, face to face communication is often called also direct communication. In face to face communication measured from the aspect of the number communicant confronted communicator then it can be classified into two types:

1) Interpersonal communication is communication between communicator with a communicant. This communication is considered to be most effective in terms of changing one's attitude, opinion, or behaviour because of its dialogical nature of the conversation.

2) Group communication is communication with a number of people as communicants in communication that cause impact and consequences.

b) Media Communication Process

Media communication is also called indirect communication and as a consequence, the backflow does not occur when communication is launched. Based on the number, the targeted communicant is classified into media and non-mass media.

1) Mass media communication is the mass media used in communication if the communicant a lot and reside far. Mass media that are widely used in everyday life generally are newspapers, radio, television, and movies in theatres, operating in the fields of information, education, and recreation or in other terms: lighting, education, and entertainment.

2) Non-mass media communication is generally used in communications for certain people or groups. Letters, telephones, telegrams, telex, bulletin boards, posters, banners, pamphlets, brochures, folders, CB radio or amateur radio, CCTV, documentary films, videotapes. Non-mass media communication has no power simultaneously and communicant is not mass. 


\section{Social Relationships Theory}

This theory is proposed by Melvin L. De Fleur, explaining that informal social relationships play an important role in changing one's behavior when exposed to communication messages. Messages are delivered through an intermediate/indirect (opinion leader). Opinion leaders are people who can informally influence the actions or attitudes of others, whether they are looking for information (opinion seekers), or who simply receive information passively (opinion recipient). Nevertheless, in essence, messages of communication are more widely accepted by individual relationships than directly from the mass media. Information is spread through social relationships within society. This theory is related to the theory of Two Step Flow Communication. Assumptions in social relations theory:

1) Information moves to people who are relatively knowledgeable (well informed).

2) Information moves from those people through interpersonal channels (interpersonal channels)

3) Opinion Leaders not only forward information but also interpretations of the communication messages they receive.

4) An opinion leader plays an important role in helping the formation of perceptions and interpretations of the audience around in response to their communication messages.

\section{Corporate Social Responsibility (CSR) Definition}

Various definitions are given for the concept of CSR. From the words 'corporate', 'social' and 'responsibility' contained in this term, CSR can be defined as the responsibility held by a company to the society in which the company stands or runs its business. In Indonesia the Government has set the CSR to be implemented by a company that exists in Indonesia in Law No.40 of 2007 on Limited Liability Company (Perseroan Terbatas) article 74:

The Company which carries out its business activities in the field and/or related to natural resources is obliged to carry out the Social and Environmental Responsibility.

The definition of CSR strongly determines the CSR program audit approach. Unfortunately, there is no definition of CSR that is universally accepted by various institutions. Some of the definitions of CSR below show the diversity of CSR understanding by various organizations (Suparmo, 2011; Dewi et al., 2017; Nuryani et al., 2018).

a) The initial definition is called the outcome of thinking of Keith Davis (1973), who argues that "CSR is the firm's consideration of, and response to, issues beyond the narrow economic, technical, and legal requirements of the firm".

b) The definition of Archie Carroll (1979), is broader and more acceptable to academics and practitioners who define CSR as follows: "CSR is the social responsibility of business encompasses the economic, legal, ethical, and discretionary expectations that society has of the organization at a given point in time." The definition of Carrol contains a broader meaning. In addition to incorporating the economic, legal, and ethical components, Carrol argues in CSR that there is an option (discretionary) of the expression of society going to the corporation or organization over a period of time. Such a definition actually also provides a deep space of thought and can be translated into different contexts.

c) European Union Commission. "Concept whereby companies integrate social and environmental concerns in their business operations and their interactions with their stakeholder on a voluntary basis".

At the beginning of its development, the most common form of CSR is the provision of assistance to local organizations and poor communities in developing countries. This CSR approach based on these charitable and humanitarian motivations is generally done ad-hoc, partially and unorganized. CSR at this level just simply does well and to look good. Companies that do include in the category of "impressive company", which is more concerned with "charm spreading" (promotion) rather than "stocking work" (empowerment) (Suharto, 2006).

Phase of Corporate Social Responsibility (CSR)

According to Wibisono (2007), there are four phases of CSR:

1) Planning phase

This stage consists of three main steps: Awareness Building, CSR Assessment, and CSR Manual Building.

Masrul, -. (2018). Communications interaction of mining company to community in corporate social responsibility program implementation. International Research Journal of Management, IT and Social Sciences, 6(1), 42-54. https://doi.org/10.21744/irjmis.v6n1.482 
Awareness Building is the main step to build awareness of the importance of CSR and management commitment, this effort can be seminars, workshops, and others. CSR Assessment is an effort to map the condition of the company and identify aspects that need to get priority attention and appropriate steps to building a corporate structure that is conducive to the effective implementation of CSR. The next step is to build a CSR Manual Building, can be through benchmarking, digging from referrals, or requesting the help of independent experts from outside the company. These guidelines are expected to provide clarity and uniformity of mindset and pattern of action of all elements of the company in order to achieve the implementation of an integrated, effective, and efficient program.

2) Implementation phase

At this stage, there are several important points: (organizing) resources, staffing, direction, supervision (control), controlling, planning, and evaluation. Implementation stage consists of three main steps are socialization, implementation, and internalization

3) Evaluation phase

The evaluation stage needs to be done consistently over time to measure the effectiveness of CSR implementation.

4) Reporting

Reporting is required in order to build information systems for both decision making and the need for material and relevant disclosure of information about the company.

\section{Corporate CSR Communications}

Communication CSR is communication about CSR activities designed and distributed by the company itself. In general, CSR is defined as an organization's social obligations. This obligation is inherent in the policies and activities of the organization with the aim of achieving economic, social, and environmental sustainability.

Attention and involvement of many parties make CSR an important issue so the company must be careful in all its activities and its impact on the whole society. Companies that wish to gain trust and legitimacy through CSR activities must have the capacity to meet stakeholder needs and communicate with their stakeholders effectively. The function of communication is central to CSR management, the Company must provide information on its social responsibilities and other related messages to its employees, customers and other stakeholders, and in general, to the entire community with various communication tools. Until now there is still criticism that questioned the company's motives to run CSR. The criticism may not be groundless, especially if the company uses CSR communications as its normal performance polish. However, there is hope for an increase incongruence between communication and action. There are four things that make non-financial reports, including CSR reports or sustainability reports, are very important:

1) Improve the company's reputation. The more transparent the company in the aspects demanded by all its stakeholders, the higher the company's reputation.

2) Serving the demands of stakeholders. Stakeholders are those who are affected by the company and can influence the company in achieving its objectives. Those who are affected by their lives are entitled to know the aspects that come into contact with their lives. While those who influence the company can also really need to know the right information, so that their influence can be directed at the right destination.

3) Helping companies to make decisions. A good performance report will certainly include indicators that will help the company understand its strengths and weaknesses.

4) Makes investors understand the company's performance easily. There is a high need for investors to know the true performance of the company. Investors in the long term really want to know whether invested capital is safe or not. Companies that have high social and environmental performance have a better chance of continuing their business.

Good CSR communication must be reliable, informative, educational, and avoid excessive emotion. CSR communications must meet aspects of timeliness, accessibility, presentation and organized, and can interact with stakeholders.

\section{Interaction}

Interaction is a reciprocal relationship among individuals and individuals, individuals with groups, groups with groups. Interaction is also a process of communication among people to influence each other's feelings and actions. It has become the power of human beings as social beings that communication is very important and its influence on 
fellow human beings. The success of a person establishing relationships with colleagues is also measured by how great his ability to communicate.

Similarly, the mining company PT. Anugrah Harisma Barakah (AHB), how it interacts with the Pongkalaero village community in implementing the Program (Corporate Social Responsibility) as a form of responsibility for them, because they can measure the company's success to preserve the environment. In Implementation of Corporate Social Responsibility (CSR) program implemented by PT. Anugrah Harisma Barakah (AHB) will influence the interaction between the company and the community. By using Social Relationships Theory approach is a theory that confirms that social relationships informally play an important role in changing one's behavior when exposed to communication messages. The purpose of this theory is that if a person receives further information it will channel that information to other individuals, so in theory, this information process takes place through two stages: First, information moves from people who are relatively well informed; Second, information moves from people through interpersonal channels. This communication situation is known as two-step flow of communication. Based on the explanation, it can be described in the following conceptual framework scheme:

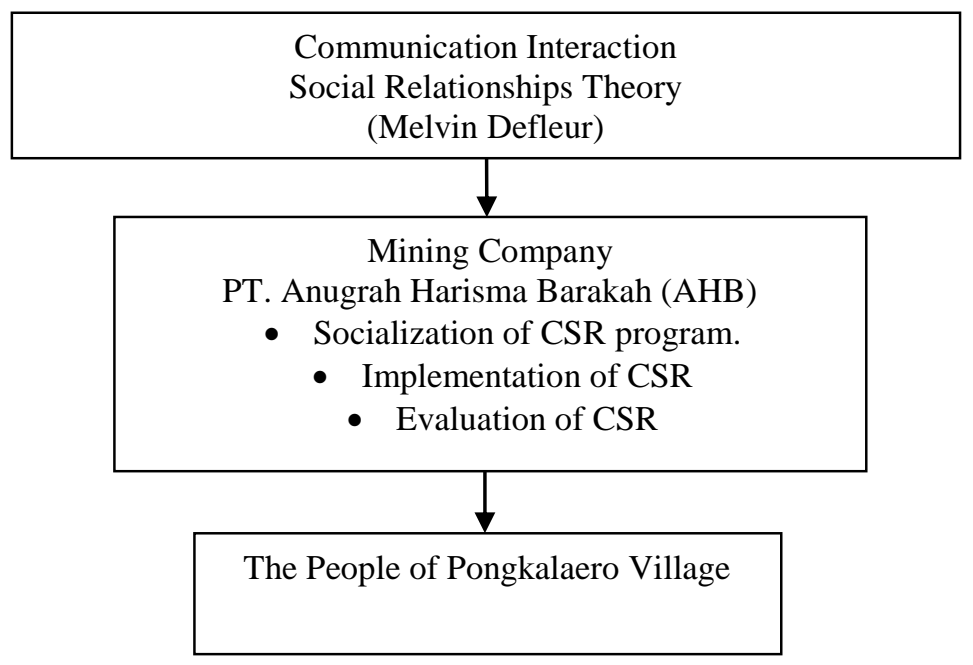

\section{Research Location}

This research was conducted at PT. Anugrah Harisma Barakah (AHB) which has conducted exploration of quarry mining in the area of Pongkalaero village, South Kabaena Subdistrict, Bombana Regency. Selection of this location so that researchers can obtain a more complete explanation for scientific research and development of knowledge.

\section{Subjects and Research Informants}

Subjects in this research are the mining of PT. Anugrah Harisma Barakah $(A H B)$ and the community in the company's area.

\section{Research Informant}

Informants are people who know a lot and directly involved with the focus of the problem so that researchers can summarize the important information in the focus of research. Informants in this study amounted to eight people.

\section{The technique of Determining Informants}

To obtain data for the benefit of research as well as representative results, the determination of informants in this study using purposive sampling technique, informants are determined based on the consideration that the informant can provide accurate information and is considered representative in obtaining data related to CSR PT AHB.

Masrul, -. (2018). Communications interaction of mining company to community in corporate social responsibility program implementation. International Research Journal of Management, IT and Social Sciences, 6(1), 42-54. https://doi.org/10.21744/irjmis.v6n1.482 


\section{Data Collection Technique}

To obtain valid and objective data, then in this research used data collecting technique such as Observation, conducting direct observation about the interaction of company and society in implementing CSR program. Interviews, obtaining data used in this study by using interviews with informants, the community and the company related CSR program that is implemented. Documentation, Data obtained through the study of several kinds of literature related to CSR, of the theoretical references that are relevant to reading books, newspapers, and the internet.

\section{Types and Data Sources}

The type of data used is qualitative data sourced from the interview, observation with direct observation of research location and analysis of written materials. Interview about how the community interaction with the company related to the implementation of the CSR program in Pongkalero Village by conducting a direct observation of the research object. The qualitative research method is a research procedure that produces descriptive data in the form of written or oral words of the people and behavior that can be observed from the people (the subject) itself. (Bogdan and Taylor in Moleong, 2007: 4). In this study, the data to be obtained by the source can be classified from two sources:

a) Primary data is data obtained through observation and collected from informants directly, using interview guidelines.

b) Secondary data is data collected through literature study and literature related to CSR of a company.

\section{Data analysis technique}

The data and information collected, whether primary or secondary data, through observation, interview, and documentation are tabulated on the basis of the same pattern. Tabulated data will then be analyzed descriptively. Miles and Huberman (1992: 16), provide a way of data analysis with data reduction, data presentation, and data verification.

1) Data reduction is the process of sorting the data collected in field notes into the data classification, determining the parts to be removed, sharpened and developed.

2) Presentation of data is a process of grouping data into an attempt to conclude data, which will be done with a description containing thematic explanations in accordance with the results of field findings.

3) Verification is an attempt to re-check the field records to re-examine the truth so that this can be obtained by agreement with the object of research.

\section{Results and Discussions}

PT. Anugrah Harisma Barakah $(A H B)$ is a nickel mining company operating on Kabaena Island, precisely in Pongkalaero Village, Kabaena district south of Bombana Regency. The company obtained a mining permit (IUP) under the mineral law, the decision of the Governor of Southeast Sulawesi Province declared: 828 dated December 31 , 2008 on approval of reserve of 3,084 hectares in Buton Regency and Bombana Regency; Governor Decree Number: 815 of 2009 dated December 17, 2009 concerning approval of exploration mining business license in the same area with 3,084 hectares; Decision of the Governor Number: 435 Year 2010 dated July 26, 2010 concerning Approval of Exploration IUP to IUP of Production Operation, covering 3,084 hectares in same area

PT. AHB is a mining subsidiary of PT Billi Indonesia. The company has conducted social assistance in 2012 , hardening of road expansion, educational facilities, and community development assistance around the mine's circle. but not in the Corporate Social Responsibility (CSR) division, but in the COMDEV division. In conducting social responsibility, the company interact with the community by meeting with community leaders in Pongkalaero village. 


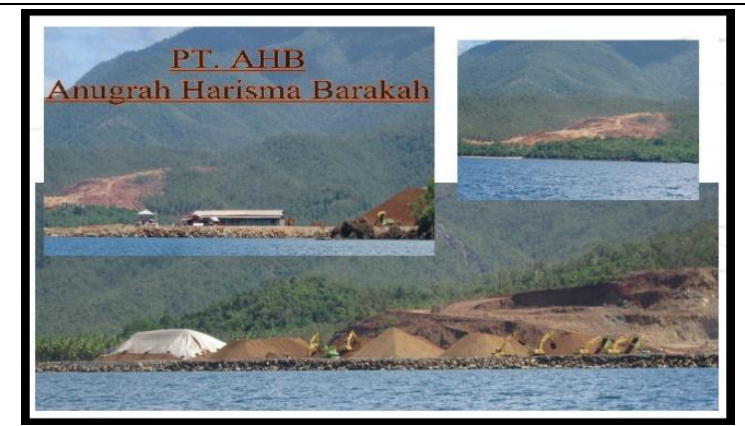

Figure 1. Location of PT. Anugrah Harisma Barakah (AHB)

\section{Profile of Pongkalaero Village Society}

The Pongkalaero Village community is based on the data of BPS-Statistics of Bombana Regency in 2012 have a population of 1,362 people, consisting of 642 men and 720 women, with $100 \%$ Moslem, and the majority profession of farmers and fishermen, etc. To support the process of social and cultural activities, the construction of educational infrastructure, health, and means of worship are very important because it affects social and cultural activities. Social facilities that have been there before such as (a) educationfacilities : consist of Early childhood education programs (PAUD): 3, Elemntary School (SD): 2, Junior High School (SMP): 1, and Vocational High School (SMK): 1, (b) Worship facility: 2 health centers: 1 (c) Village government facilities.

\section{Communication Interaction of Mining Company PT. AHB and the Pongkalaero Village community}

In analyzing the communication interaction process of PT. AHB and Pongkalaero villagers, the authors use three stages are socialization, implementation, and evaluation.

a) CSR Socialization

Form of socialization

Corporate social responsibility to the environment is essential for any company to manage, manage and use the environment well, not only benefit and improve the business efficiency of every company but also for the environment and social impact in the future. In the process of social responsibility to the environment, the company PT. Anugrah Harisma Barakah (AHB) did not conduct optimal socialization so that the principle of Corporate Social Responsibility $(C S R)$ benefits to the community is still blurred. It is a bias in the implementation process of environmental social responsibility that is not implemented in Pongkalaero village, the implementation is relatively closed where only done in exploitation area such as explanation from Mr. Ir. Eddy Darmo. S, as the site manager of PT. Anugrah Harisma Barakah (AHB). The description of the information reinforces that CSR development on existing companies within the vicinity of Pongkalaero village is not maximal because more dominant meetings are held on certain community figures with the assumption that the responsibility is only done in the company area. Even the other opinion of the company that information about the environment is not a right in the community. While the form of socialization only use opinion leaders or people who are considered influential in the community whether because of his figure or because he is a leader in the community.

\section{Intensity of Socialization}

The condition of life of the people who according to his character used to live farming would be difficult to change from farming character to become a living character of mining. The effort to promote Corporate Social Responsibility from mining companies has been discouraged but due to the lack of enthusiasm of the community and the lack of public understanding about mining, it becomes an obstacle to socialization. Therefore the company needs special methods to deal with the community as a concern of the law. In public recognition that what has been discussed is the price of public land affected by the mining IUP location, while on other matters never implemented.

\section{b) CSR Program Implementation}

Corporate Social Responsibility implemented by PT. Anugrah Harisma Barakah $(A H B)$ is an integrative part of the business process by the Company. PT (AHB) has a policy that regulates the implementation of CSR, but it

Masrul, -. (2018). Communications interaction of mining company to community in corporate social responsibility program implementation. International Research Journal of Management, IT and Social Sciences, 6(1), 42-54. https://doi.org/10.21744/irjmis.v6n1.482 
is also influenced by Law No.40 of Article 74 Year 2007 in line with Corporate Cultural Values. This is as expressed by Mr. Ir. Eddy Darmo S. as Site Manager of PT. Anugrah Harisma Barakah, that: PT. Anugrah Harisma Barakah $(A H B)$ took the initiative to pay attention to social interests and contribute to the advancement of living together through social and cultural economic development.

PT. Anugrah Harisma Barakah (AHB) implemented CSR because it was caused by two things, first the regulation of the government and also because of the desire of the company to conduct social activities. If linked in Wibisono (2007) regarding the company's view. Second, PT. Anugerah Harisma Barakah (AHB) has two views on CSR, namely as an effort to fulfill the obligation (compliance) and because of internal driven. Corporate Social Responsibility is not just implemented because it respects the existing regulations but has placed CSR as part of Corporate Cultural Values and business process of the company. PT. Anugrah Harisma Barakah (AHB) strives for every employee to implement social responsibility in daily life.

\section{Environmental Concern}

In Indonesia, although there has been a law that regulates the corporate social responsibility to the environment (CSR), in its application is still very minimal. Some big companies have realized the importance of CSR for them. But in most small companies the implementation of CSR is still very low. This is based on the lack of awareness or concern of small companies in the surrounding environment. Nowadays there are probably very many small companies who think that CSR will only increase their cost of expenses in the absence of reciprocity. In fact, CSR is actually very important for the company itself because it has many advantages such as;

1) Reputation development or corporate image in the view of consumers and investors

2) Eliminating environmental and social conflicts around the company

3) Enhancing cooperation with stakeholders

4) Differentiate the company from its competitors

Another important benefit here is the aspect of risk management with regard to reputation and true culture within the company and beneficial to society. So basically CSR should be applied seriously by the company. The view gives an understanding that CSR is a contribution that a company provides to the community through its core business activities, this is an investment to the community, and a program of generosity, and this is in conjunction with public policy agreements. A form of social responsibility to the environment that is done by PT. Anugerah Harisma Barakah $(A H B)$ is a tree seedling in the area of exploitation, as in the picture below.

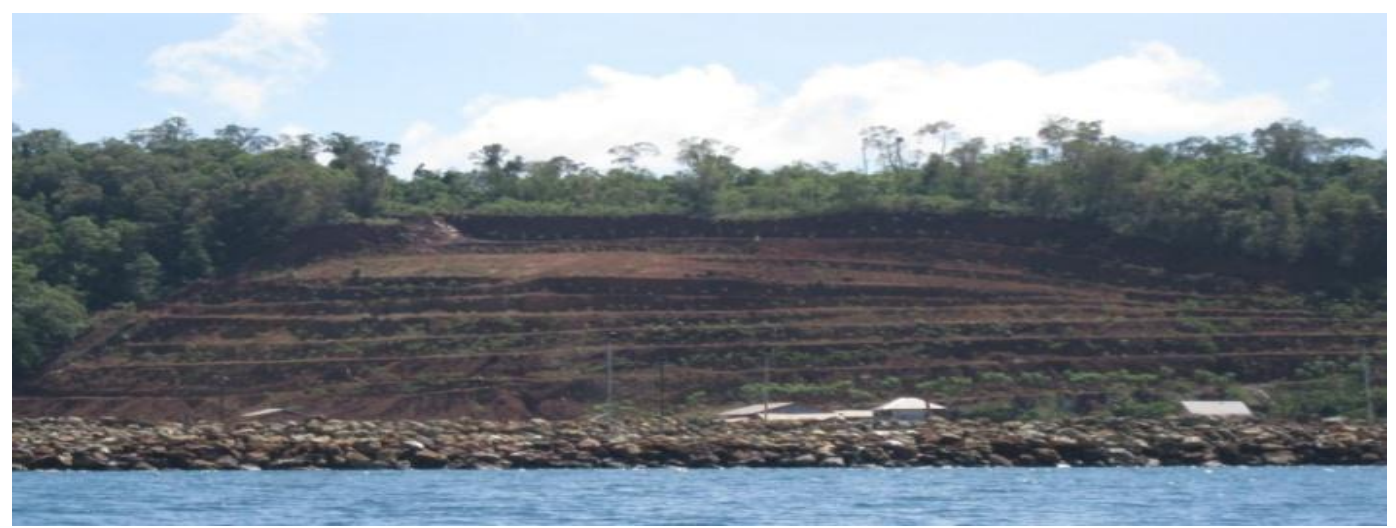

Figure 2. The replanting of trees in the exploitation area of PT. Anugrah Harisma Barakah (AHB)

\section{Human Resource Development}

Development of human resources $(H R)$ is to be hoped for each community group. Various progress can be felt if a community prioritizes human resource development. Human potential is the gift of the creator. Because it will create a grace in the environment of human life if human resources have been adequate. The presence of mining companies through corporate social responsibility from PT. AHB is very potential for the community around the mine to solve the problem of social life needs of the community on the radius of the company. Non-transparent and unclean conditions in the use of CSR caused no significant increase in human resources before and after the 
operation of mining companies in Kabaena, in particular, South Kabaena.

\section{Infrastructure}

In implementing the CSR program, PT. Anugrah Harisma Barakah (AHB) still gives attention to the needs of community infrastructure facilities that pay attention to the needs of such a priority scale of recognition part of the leadership of PT. Anugrah Harisma Barakah $(A H B)$, for example, the expansion of the $16 \mathrm{~km}$ road as a means of interconnection between villages, and procurement of vocational buildings (SMK) in South Kabaena area.

\section{Local labor}

The dream of the community around the mining company is the creation of employment and the potential allocation of the community. The limitations of the existing community around the mining company and the needs of the company and the standard of work always be a powerful tool for the company. Similarly, the pattern of nepotism in PT. AHB a mining company that has been dredging the produce on Kabaena island for many years. Even the recruitment procedure has been delegated to someone who does not necessarily understand the working mechanisms of mining companies. Of course, it will potentially lead to imbalances and not transparent in labor recruiters. The recruitment atmosphere has been done with no focus on the community around the mine so that it has difficulty in controlling.

\section{Evaluation of the CSR Program}

Achievement of goals and work goals is always measured by measurable monitoring and evaluation. The evaluation process is seen as a process other than to measure the achievement also in order to find the format toward the desired progress of a company. Therefore, if the planning work is not maximal will result in ineffective assessment indicators. Similarly, the incident at PT. AHB in the implementation of Corporate Social Responsibility (CSR ) although it has been the implementation effort because the evaluation system is less than the maximum as the strategy used in an effort to achieve company goals. The data obtained from the measurement results will be used as the next program situation analysis. There is an underlying sequence or process before evaluating:

1) Develop concepts and conduct initial research. The concept needs to be carefully planned before execution of the message and a trial to check the suitability of the draft made with the execution of the message.

2) With the experiments conducted, the evaluator tries to find responses from the audience. Responses from these audiences are important to measure the effectiveness of the message delivered.

A series of measurement scale shows that related concern to the environment of the company when conducting the evaluation does not include the community because the area where it exists outside Pongkalero village community settlement so that the company put special team. Similarly, infrastructure and human resource development to local labor capacity are still not transparent, and even its control has been neglected.

CSR is done by PT. Anugrah Harisma Barakah can not be separated from how the company establishes good communication relationship with Pongkalaero Village community, because the implementation of CSR also allows the two-way communication between companies with the community but looks mediocre without any significant influence.

Communication is the process by which an idea flows from one source to one or more recipients with a view to changing behavior, says Everett M. Rogers. The definition emphasizes that in communication there is a process of passing ideas, notions, symbols, and in the process of involving others. However, it is actually in the communication process itself that other person can be himself. In the aspect of communication science created between PT. Anugrah Harisma Barakah and Pongkalaero village community through the corporate social responsibility program are not effective because between the two does not affect each other that can be measured and between the mining companies and the people of Pongkalaero Village do not carry out their respective roles. If the occurrence of conditioned communications interaction is ineffective as well as between the village community Pongkalaero mutually suspect as existing then in the implementation of CSR PT. AHB is not synonymous with the Social Relationships Theory by Melvin L. DeFleur who explains that informal social relations play an important role in changing one's behavior when exposed to a communication message. Messages are delivered through an intermediate/indirect (opinion leader).

Masrul, -. (2018). Communications interaction of mining company to community in corporate social responsibility program implementation. International Research Journal of Management, IT and Social Sciences, 6(1), 42-54. https://doi.org/10.21744/irjmis.v6n1.482 


\section{Conclusion}

Based on the Research Result of Mine Company Communication Interaction PT. AHB and Community in Implementation of Corporate Social Responsibility Program (CSR), can be drawn the conclusion:

1) That the communication interaction conducted by opinion leader by mining company PT. Anugrah Harisma Barakah (AHB) to the Pongkalero Village community in the implementation of Corporate Social Responsibility (CSR) program caused the problem because there was a suspicion in the community towards the opinion leader, only community leaders are close to the companies involved in the CSR program implementation process.

2) That CSR implementation of PT. AHB on the community does not get a good response and less useful in society.

\section{Recommendation}

Based on the conclusions described above, it can be suggested as follows:

1) Communication interaction made by the company PT. Anugrah Harisma Barakah (AHB) should be transparent to the community by interacting directly like a meeting to discuss the things that the community needs.

2) Corporate Social Responsibility (CSR) Program PT. Anugrah Harisma Barakah (AHB) that has been done such as road improvements and school building procurement assistance is considered not maximal, so it is necessary to determine the new and better form in optimizing the potential of Pongkalaero Village community as the character of the local community life.

Conflict of interest statement and funding sources

The author declared that he has no competing interest. The study was financed by personal funding.

\section{Statement of authorship}

The author has a responsibility for the conception and design of the study. The author has approved the final article.

\section{Acknowledgments}

I would like to express my gratitude to the leaders and colleagues who always provide inspiration so that this research has been conducted well. Particularly, through this topic, I thank the community around mining activities, especially the people of Pongkalaero Village, South Kabaena Subdistrict, Bombana, Southeast Sulawesi who have been willing to provide information to researchers. I also did not forget to express my gratitude to the companies who have collaborated with us so that this research can be useful for the community and the government. 


\section{References}

Bogdan, R., \& Taylor, S. J. (1990). Looking at the bright side: A positive approach to qualitative policy and evaluation research. Qualitative Sociology, 13(2), 183-192. https://doi.org/10.1007/BF00989686

Cangara, H. (2011). Komunikasi Politik; Teori, Konsep, dan Strategi. Jakarta. Rajawali Pers.

Carroll, A. B. (1979). A three-dimensional conceptual model of corporate performance. Academy of management review, 4(4), 497-505. https://doi.org/10.5465/amr.1979.4498296

Davis, K. (1973). The case for and against business assumption of social responsibilities. Academy of Management journal, 16(2), 312-322. https://doi.org/10.5465/255331

Dewi, I. G. A. A. O., \& Dewi, I. G. A. A. P. (2017). Corporate social responsibility, green banking, and going concern on banking company in Indonesia stock exchange. International Journal of Social Sciences and Humanities, 1(3), 118-134. https://doi.org/10.29332/ijssh.v1n3.65

Effendy, B. (2005). Islamic economic institutions in Indonesia: A religio-political perspective. Islam in Southeast Asia: Political, social and strategic challenges for the 21st century, (11), 64.

Effendy, O. U. (1990). Ilmu komunikasi teori dan praktek. Remaja Rosdakarya.

Effendy, O. U. (2003). Ilmu, teori dan filsafat komunikasi.

Effendy, O. U. (2008). Dinamika komunikasi. Remaja Rosdakarya.

Miles, M. B., \& Huberman, A. M. (1992). Analisis data kualitatif.

Moleong, L. J. (2007). Metodologi Penelitian Kualitatif edisi revisi Bandung: PT Remaja Rosdakarya Offset. ISBN 979-514-051-5.

Nuryani, N. N. J., Satrawan, D. P. R., Gorda, A. A. N. O. S., \& Martini, L. K. B. (2018). Influence of human capital, social capital, economic capital towards financial performance \& corporate social responsibility. International Journal of Social Sciences and Humanities, 2(2), 65-76. https://doi.org/10.29332/ijssh.v2n2.128

Suharto, E. (2006). Membangun Masyarakat Membangun Rakyat. Kajian Strategis Pembangunan Sosial dan Pekerja Sosial.

Suparmo, L. (2011). Aspek Ilmu Komunikasi dalam Public Relations. Jakarta: Indeks.

Wibisono, Y. (2007). Membedah konsep \& aplikasi CSR: corporate social responsibility. Fascho Pub.

Masrul, -. (2018). Communications interaction of mining company to community in corporate social responsibility program implementation. International Research Journal of Management, IT and Social Sciences, 6(1), 42-54. https://doi.org/10.21744/irjmis.v6n1.482 


\section{Biography of Author}

\begin{tabular}{|l|l|}
\hline & $\begin{array}{l}\text { Masrul, S.Ag., M.Sc., was born in Enano, September 13, 1971. Residing at Jalan Belibis } \\
\text { III No. 4a, Kendari. The last education was Master of Science in Communication } \\
\text { Science, and until now is a permanent lecturer at the Faculty of Social and Political } \\
\text { Sciences at the University of Halu Oleo. } \\
\text { Email: masrul1971@ @mail.com }\end{array}$ \\
\hline
\end{tabular}

